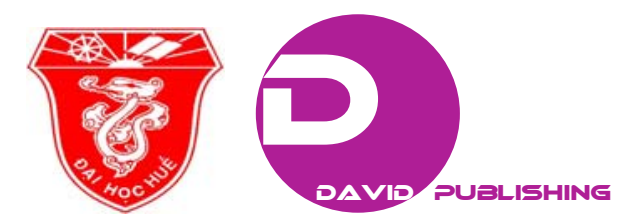

\title{
Determination of Ileal Amino Acid Digestibilities of Some By-products for Chickens
}

\author{
Ho Trung Thong ${ }^{1}$, Ho Le Quynh Chau ${ }^{1}$ and Vu Chi Cuong ${ }^{2}$ \\ 1. Faculty of Animal Husbandry and Veterinary Medicine, College of Agriculture and Forestry, Hue University, Thua Thien Hue \\ 530000, Vietnam \\ 2. National Institute of Animal Husbandry, Thuy Phuong, Tu Liem District, Hanoi, Vietnam
}

\begin{abstract}
The aim of this study was to determine the standardized ileal digestibility of amino acids in six by-product ingredients for broiler, i.e., copra meal, rapeseed meal, feather meal, hydrolyzed poultry meal, meat and bone meal, and shrimp head meal. Luong Phuong chickens at $35 \mathrm{~d}$ of age were used in the trials. Dietary protein in all assay diets was supplied solely by the test ingredient. In the case of protein-rich ingredients, dextrose was added to assay diets to obtain $20 \%$ of crude protein. Standardized ileal amino acid digestibilities were calculated by correcting the apparent ileal digestibility coefficients by basal endogenous amino acid losses. Results of study showed that the variation in ileal digestibility coefficients of amino acids was low in rapeseed meal and high in copra meal. Among animal protein meals, the lowest variation of digestibility among amino acids was observed in shrimp head meal. The high standardized ileal digestibilities of Arg, His, Leu + Ile, Thr, Trp, Val, and Phe were observed in hydrolyzed poultry meal and shrimp head meal. Meanwhile, the standardized ileal digestibility values of Lys, Thr and Trp in feather meal were very low. Meat and bone meal and feather meal were the two least digestible amino acid ingredients.
\end{abstract}

Key words: Amino acid, by-product, chicken, standardized ileal digestibility.

\section{Introduction}

It is recognized that not all the nutrients in feed ingredients are available for production purposes, and a portion of nutrients is excreted undigested or not utilized [1]. Therefore, maximizing the efficiency of nutrient utilization, especially protein and amino acid, is very important. Knowledge of amino acid digestibility coefficients in feed ingredients and the requirement of digestible amino acids for a defined production target enables the formulation of diets more close to chicken's requirements [2]. Formulating diets based on digestible amino acids allows increasing the diversity and inclusion levels of non-traditional ingredients, despite the fact that they may contain less than optimal natural amino acid profiles and are poorly digested [1]. Such formulations have significant role in developing

Corresponding author: Ho Trung Thong, associate professor, research field: animal science. countries, where highly digestible conventional ingredients are not available [1]. Many study results indicated the beneficial effects of using ileal digestible amino acids in broiler diet formulations to increase the inclusion levels of poorly digestible ingredients, such as cotton meal, canola meal, meat and bone meal [3-7]. Furthermore, diet formulations based on digestible amino acid improve the precision of formulation, offer economic benefits, ensure more predictable bird performance and reduce nitrogen output from poultry operations [1, 2, 8].

However, a question often posed by commercial nutritionists is which digestible amino acid system is the most appropriate for use in poultry diet formulation [9]. Apparent digestibility measures the digestibility of amino acids of both dietary and endogenous origins [10]. While, standardized digestibility includes a correction for endogenous amino acid secretions [11]. The choice of the 
appropriate system of digestible amino acids may depend on the diet formulation method [9]. If diets are being formulated to the least-cost using linear programming, then apparent ileal digestibility values are the most appropriate, as they take into account the endogenous cost of digestion. On the other hand, in case of formulating diets with computer simulation models, then standardized digestibility values will be relevant if the model corrects for the endogenous cost of digestion [9]. Notwithstanding, it should be appreciated that both digestible amino systems are better than the total amino acid system, and all systems have specific applications and shortcomings [9]. This study was carried out with the purpose of determining standardized ileal digestibility of amino acids in some by-product ingredients (copra meal, rapeseed meal, feather meal, hydrolyzed poultry meal, meat and bone meal and shrimp head meal) for broiler.

\section{Materials and Methods}

\subsection{Animals and Diets}

The study was performed with Luong Phuong chickens at the Poultry Research Room and Central Lab, Faculty of Animal Husbandry and Veterinary Medicine, Hue University of Agriculture and Forestry from October 2013 to January 2014. A completely randomized experimental design in a single factor experiment was applied. A total of 180 35-day-old Luong Phuong chickens (completely matured digestive system) with uniform body weight 515 $\mathrm{g} /$ chick were assigned to six treatments for evaluation of apparent ileal amino acid digestibility in six test ingredients-copra meal, rapeseed meal, feather meal, hydrolyzed poultry meal, meat and bone meal, and shrimp head meal. Each treatment was replicated five times with 30 chicks per treatment. Every two chicks (one male and one female) were housed in a cage.

Dietary protein in all assay diets was supplied solely by the test ingredient $[12,13]$. In the case of protein-rich ingredients, dextrose was added to assay diets to obtain $20 \%$ of crude protein [12]. Paper powder (3.0\%) was added as a source of fiber in diets containing animal protein meals [12]. Celite (Celite ${ }^{\circledR}$ 545RVS, Nacalai Tesque, Japan) was added at 1.5\% to all diets as a source of acid insoluble ash (AIA), which was used as an indigestible marker in the calculation of digestibility coefficients [14]. The nutritional value of test ingredients and the composition of experimental diets are presented in Tables 1 and 2.

\subsection{Experimental Procedure}

The experiment was implemented for $7 \mathrm{~d}$ following the method of Bryden and Li [12]. Diets were provided ad libitum and water was available at all times [12]. At the 8th day of experiment, all chickens were euthanized. Ileal digesta was collected as described by Bryden and $\mathrm{Li}$ [12]. The ileum was defined as the portion of the small intestine extending from Meckel diverticulum to a point of $4 \mathrm{~cm}$ proximal to the ileo-caecal junction. The contents of the lower half of the ileum were collected by gently flushing with distilled water into plastic containers. Ileal digesta of six chickens within a replication were pooled and frozen at $-20{ }^{\circ} \mathrm{C}$ immediately after collection.

\subsection{Chemical Analysis and Calculations}

Digesta samples were dried at $60{ }^{\circ} \mathrm{C}$ in forced-ventilation oven for $8 \mathrm{~h}$. Feed and dried digesta samples were ground to pass through a $0.5 \mathrm{~mm}$ sieve and stored in airtight container at $4{ }^{\circ} \mathrm{C}$ for chemical analyses. All proximate composition of samples was analyzed following AOAC procedures [15] at Central Lab, Faculty of Animal Husbandry and Veterinary Medicine, Hue College of Agriculture and Forestry, Hue University. Dry matter (DM) content of samples was determined by oven drying at $130{ }^{\circ} \mathrm{C}$ for $3 \mathrm{~h}$ as AOAC official method 930.15 [15]. Nitrogen (N) content was determined by using Kjeltec 8200 system (Foss, Sweden) following AOAC official method 
Table 1 Nutritive value of test ingredients (as fed basis).

\begin{tabular}{|c|c|c|c|c|c|c|c|}
\hline Nutritive & & Copra meal & Rapeseed meal & Feather meal & $\begin{array}{l}\text { Hydrolyzed } \\
\text { poultry meal }\end{array}$ & $\begin{array}{l}\text { Meat and bone } \\
\text { meal }\end{array}$ & $\begin{array}{l}\text { Shrimp head } \\
\text { meal }\end{array}$ \\
\hline \multirow{17}{*}{$\begin{array}{l}\text { Total amino } \\
\text { acid (\%) }\end{array}$} & Arg & 2.27 & 2.07 & 5.15 & 4.21 & 3.39 & 2.43 \\
\hline & His & 0.34 & 1.06 & 0.75 & 1.14 & 0.89 & 5.88 \\
\hline & Ile + Leu & 1.92 & 3.48 & 10.01 & 6.73 & 4.53 & 4.41 \\
\hline & Lys & 0.50 & 1.97 & 2.02 & 0.58 & 2.31 & 1.88 \\
\hline & Met & 0.30 & 0.65 & 0.49 & 1.18 & 0.68 & 0.53 \\
\hline & Phe & 0.80 & 1.77 & 3.63 & 2.52 & 1.55 & 1.71 \\
\hline & Thr & 0.61 & 1.44 & 3.50 & 2.46 & 1.57 & 1.26 \\
\hline & Trp & 0.16 & 0.41 & 0.58 & 0.41 & 0.31 & 0.20 \\
\hline & Val & 1.09 & 1.65 & 5.34 & 2.98 & 2.30 & 1.91 \\
\hline & Ala & 0.73 & 1.56 & 3.85 & 4.00 & 3.03 & 2.00 \\
\hline & Asp & 1.49 & 2.39 & 4.57 & 5.79 & 3.39 & 2.45 \\
\hline & Cys & 0.20 & 0.81 & 4.09 & 0.58 & 0.48 & 1.63 \\
\hline & Glu & 3.56 & 6.12 & 8.20 & 6.11 & 6.27 & 4.27 \\
\hline & Gly & 0.78 & 1.83 & 7.08 & 5.62 & 6.83 & 1.66 \\
\hline & Pro & 0.60 & 2.05 & 9.51 & 4.14 & 4.19 & 1.10 \\
\hline & Ser & 0.80 & 1.37 & 7.94 & 3.40 & 1.57 & 0.90 \\
\hline & Tyr & 0.56 & 0.94 & 1.96 & 1.83 & 1.05 & 1.36 \\
\hline \multirow{5}{*}{$\begin{array}{l}\text { Proximate } \\
\text { composition } \\
\text { (\%) }\end{array}$} & $\mathrm{DM}$ & 93.16 & 88.34 & 94.15 & 90.93 & 96.00 & 87.67 \\
\hline & $\mathrm{CP}$ & 19.59 & 36.08 & 85.74 & 67.41 & 51.47 & 46.18 \\
\hline & $\mathrm{EE}$ & 13.70 & 2.51 & 4.48 & 13.56 & 2.33 & 8.25 \\
\hline & CF & 13.25 & 12.09 & 0.28 & 0.45 & 2.33 & 10.12 \\
\hline & Ash & 7.02 & 6.97 & 3.64 & 6.88 & 3.91 & 14.56 \\
\hline
\end{tabular}

Table 2 Composition and nutrient content of experimental diets.

\begin{tabular}{|c|c|c|c|c|c|c|}
\hline \multirow{2}{*}{$\frac{\text { Ingredient }}{\text { Copra meal }}$} & \multicolumn{6}{|c|}{ Ratio (\%) } \\
\hline & 94.00 & - & - & - & - & - \\
\hline Rapeseed meal & - & 55.50 & - & - & - & - \\
\hline Feather meal & - & - & 23.30 & - & - & - \\
\hline Hydrolyzed poultry meal & - & - & - & 30.00 & - & - \\
\hline Meat and bone meal & - & - & - & - & 38.86 & - \\
\hline Shrimp head meal & - & - & - & - & - & 45.53 \\
\hline Dextrose & - & 38.05 & 65.55 & 58.85 & 49.99 & 43.32 \\
\hline Soybean oil & 2.00 & 2.00 & 6.00 & 6.00 & 6.00 & 6.00 \\
\hline Paper powder & - & - & 3.00 & 3.00 & 3.00 & 3.00 \\
\hline Vitamin premix $^{*}$ & 0.20 & 0.20 & 0.20 & 0.20 & 0.20 & 0.20 \\
\hline Mineral premix ${ }^{* *}$ & 0.25 & 0.25 & 0.25 & 0.25 & 0.25 & 0.25 \\
\hline $\mathrm{CaCO}_{3}$ & 1.45 & - & - & - & - & - \\
\hline DCP & 0.40 & 2.30 & - & - & - & - \\
\hline $\mathrm{NaCl}$ & 0.20 & 0.20 & 0.20 & 0.20 & 0.20 & 0.20 \\
\hline Celite & 1.50 & 1.50 & 1.50 & 1.50 & 1.50 & 1.50 \\
\hline Total & 100 & 100 & 100 & 100 & 100 & 100 \\
\hline \multicolumn{7}{|l|}{ Nutrient content, as-fed basis } \\
\hline Protein (\%) & 18.41 & 20.02 & 19.98 & 20.22 & 20.00 & 21.02 \\
\hline Metabolizable energy (kcal/kg) & 2,223 & 995 & 1,127 & 1,383 & 1,135 & 1,259 \\
\hline
\end{tabular}


984.13 [15]. Crude protein contents of the samples were calculated as $N \times 6.25$. Ether extract, crude fiber and total ash contents of the samples were determined following AOAC official methods 920.39, 978.10, and 942.05 [15], respectively. Amino acids in digesta and feed were analyzed using LC/MS/MS system with EZ:faast ${ }^{\mathrm{TM}}$ amino acids analysis kit (Phenomenex) at Hai Dang Chromatography Scientific Services Joint Stock Company (Ho Chi Minh city, Vietnam). AIA content was assayed following the method of Vogtmann et al. [16].

Standardized ileal amino acid digestibilities were calculated by correcting the apparent ileal digestibility coefficients by basal endogenous amino acid losses [17], as shown in Eq. (1) [14]:

SID $(\%)=$ AID $(\%)+[$ basal endogenous amino acid losses (g/kg DM intake)/amino acid content of the raw material $(\mathrm{g} / \mathrm{kg} \mathrm{DM}) \times 100$ ]

where, AID (\%): apparent ileal digestibility coefficient; SID (\%): standardized ileal digestibility coefficient; DM: dry matter.

In the authors' previous study, basal endogenous amino acid losses had been determined based on the concentration of amino acids in ileal digesta collected from chickens fed protein free diet, AIA contents in diet and the ileal digesta [17].

\subsection{Data Analysis}

The mean value was calculated from five replicate values. The data were analyzed using Microsoft excel 2007.

\section{Results and Discussion}

The crude protein content and amino acid composition of test ingredients (Table 1) are within the ranges reported in Ref. [18]. The apparent and standardized ileal digestibilities of amino acids of six test ingredients are presented in Tables 3 and 4 . The apparent ileal digetibilities of protein or amino acids were lower than the standardized ileal digetibilities. The variations between apparent and standardized ileal digetibilitie values were low in protein-rich ingredients, and vice versa.

There are no remarkable differences in the ileal digestibility coefficients of amino acids of rapeseed meal. This finding was similar to the previous study conducted by Ravindran et al. [13]. Regarding to copra meal, high variation of the standardized ileal

Table 3 Apparent ileal amino acid digestibility of test ingredients.

\begin{tabular}{lllllll}
\hline \multirow{2}{*}{ Amino acid } & \multicolumn{5}{c}{ Apparent ileal digestibility (\%) } \\
\cline { 2 - 7 } & Copra meal & Rapeseed meal & Feather meal & $\begin{array}{l}\text { Hydrolyzed } \\
\text { poultry meal }\end{array}$ & $\begin{array}{l}\text { Meat and bone } \\
\text { meal }\end{array}$ & Shrimp head meal \\
\hline Arg & 83.54 & 82.12 & 66.23 & 86.45 & 72.65 & 80.14 \\
His & 66.92 & 79.72 & 53.69 & 79.36 & 68.75 & 75.76 \\
Ileu + Leu & 68.00 & 73.79 & 68.44 & 79.89 & 72.14 & 77.90 \\
Lys & 63.44 & 71.4 & 51.55 & 79.09 & 64.21 & 74.01 \\
Met & 70.97 & 72.88 & 54.69 & 74.19 & 67.79 & 78.19 \\
Phe & 67.58 & 73.52 & 59.17 & 79.14 & 64.65 & 75.85 \\
Thr & 61.09 & 65.53 & 50.82 & 79.49 & 60.81 & 73.87 \\
Trp & 69.23 & 75.19 & 46.43 & 76.01 & 53.67 & 74.61 \\
Val & 73.31 & 71.45 & 64.33 & 75.66 & 68.88 & 76.99 \\
Ala & 66.62 & 73.85 & 75.96 & 73.91 & 68.99 & 71.99 \\
Asp & 59.33 & 70.08 & 66.70 & 67.74 & 62.89 & 77.26 \\
Cys & 58.85 & 72.94 & 45.30 & 67.88 & 48.02 & 75.85 \\
Glu & 62.94 & 82.47 & 65.77 & 76.23 & 72.68 & 76.48 \\
Gly & 60.87 & 71.2 & 79.26 & 73.07 & 70.80 & 72.87 \\
Pro & 55.84 & 71.01 & 71.04 & 80.74 & 72.88 & 72.93 \\
Ser & 55.04 & 69.29 & 74.77 & 69.08 & 64.94 & 72.15 \\
Tyr & 66.27 & 73.55 & 57.44 & 72.64 & 69.82 & 74.23 \\
\hline
\end{tabular}


Table 4 Standardized ileal amino acid digestibility of test ingredients.

\begin{tabular}{lllllll}
\hline \multirow{2}{*}{ Amino acid } & \multicolumn{5}{c}{ Standardized ileal digestibility (\%) } \\
\cline { 2 - 7 } & Copra meal & Rapeseed meal & Feather meal & $\begin{array}{l}\text { Hydrolyzed } \\
\text { poultry meal }\end{array}$ & $\begin{array}{l}\text { Meat and bone } \\
\text { meal }\end{array}$ & Shrimp head meal \\
\hline Arg & 84.80 & 84.33 & 68.49 & 88.52 & 74.75 & 82.43 \\
His & 71.36 & 82.00 & 61.90 & 83.39 & 72.99 & 76.27 \\
Ileu + Leu & 71.70 & 77.06 & 71.32 & 83.11 & 76.04 & 81.04 \\
Lys & 67.49 & 73.04 & 55.63 & 82.84 & 66.39 & 76.11 \\
Met & 74.58 & 75.53 & 63.51 & 76.97 & 71.73 & 82.15 \\
Phe & 71.18 & 76.13 & 62.40 & 82.63 & 69.27 & 79.14 \\
Thr & 69.38 & 71.18 & 56.73 & 85.81 & 68.84 & 81.72 \\
Trp & 75.74 & 79.23 & 53.61 & 83.72 & 61.95 & 84.43 \\
Val & 77.23 & 75.59 & 67.59 & 80.03 & 73.50 & 81.34 \\
Ala & 70.77 & 76.96 & 79.16 & 76.22 & 71.48 & 74.92 \\
Asp & 63.00 & 73.76 & 71.58 & 70.63 & 66.92 & 81.62 \\
Cys & 70.42 & 77.44 & 47.57 & 79.93 & 59.91 & 78.58 \\
Glu & 64.99 & 84.39 & 69.40 & 79.88 & 75.58 & 79.82 \\
Gly & 67.05 & 75.44 & 82.04 & 75.69 & 72.56 & 78.56 \\
Pro & 62.36 & 74.09 & 72.72 & 84.59 & 75.22 & 79.92 \\
Ser & 60.37 & 74.32 & 76.97 & 72.93 & 71.71 & 81.45 \\
Tyr & 71.43 & 78.44 & 64.38 & 77.43 & 76.64 & 78.33 \\
\hline
\end{tabular}

amino acid digestibilities was observed, ranging from $60.37 \%$ to $84.80 \%$. The difference in quality of rapeseed meal and copra meal may be explained due to the difference in concentrations of limiting amino acids and bulking properties.

The variation of digestibility between amino acids in shrimp head meal was lower than that in other animal protein ingredients. Standardized ileal digestibility of amino acids ranged from $74.92 \%$ to 84.43\% in shrimp head meal. Meanwhile, the standardized ileal digestibility values of amino acid in feather meal, meat and bone meal ranged from $47.57 \%$ to $82.04 \%$ and from $59.91 \%$ to $76.64 \%$, respectively. Among the essential amino acids, the standardized ileal digestibility values of Lys, Thr and Trp in feather meal were very low. On the other hand, the standardized ileal digestibilities of Arg, His, Leu + Ile, Thr, Trp, Val and Phe were very high in hydrolyzed poultry meal and shrimp head meal (Table 4). The low standardized ileal digestibility of amino acids was observed in feather meal, meat and bone meal. The variation in quality of meat and bone meal is likely to be caused by the correlation variability between muscle protein and collagen content in raw materials, or by processing conditions of the meals [7, $19,20]$. In poor-quality meat and bone meal, $50 \%-65 \%$ of total protein may be collagen [1]. Collagen is the major protein in bone, connective tissue, cartilage and tendon. Eastoe and Long [21] found that collagen is severely deficient in most indispensable amino acids and poorly digested because of the low level of collagenase in digestive tract.

\section{Conclusions}

The variation in ileal digestibility coefficients of amino acids was low in rapeseed meal and high in copra meal. Among animal protein meals, the lowest variation of digestibility between amino acids in shrimp head meal was observed. The high standardized ileal digestibilities of Arg, His, Leu + Ile, Thr, Trp, Val and Phe was observed in hydrolyzed poultry meal and shrimp head meal. Meanwhile, the standardized ileal digestibility values of Lys, Thr and Trp in feather meal were very low. Meat and bone meal and feather meal were the two least digestible amino acid ingredients. 


\section{References}

[1] Ravindran, V. 2011. Poultry Feed Availability and Nutrition in Developing Countries-Advances in Poultry Nutrition. Rome, Italy: FAO.

[2] Hoehler, D., Lemme, A., Ravindran, V., Bryden, W. L., and Rostagno, H. S. 2006. "Feed Formulation in Broiler Chickens Based on Standardized Ileal Amino Acid Digestibility." In Proceedings of VIII International Symposium on Aquatic Nutrition.

[3] Fernandez, S. R., Zhang, Y., and Parsons, C. M. 1995. "Dietary Formulation with Cottonseed Meal on a Total Versus a Digestible Amino Acid Basis.” Poultry Science 74 (7): 1168-79.

[4] Ravindran, V., and Bryden, W. L. 1999. "Evaluation of Meat and Bone Meal in Broiler Starter Diets Formulated on the Basis of Total or Digestible Amino Acids.” Pro. Aust. Poult. Sci. Sym. 11: 169.

[5] Ravindran, V., and Bryden, W. L. 1999. "Evaluation of Broiler Diets Containing Graded Levels of Cottonseed Meal and Formulated on the Basis of Total or Digestible Amino Acids.” Pro. Aust. Poult. Sci. Sym. 11: 168.

[6] Ravindran, V., Hew, L. I., and Bryden, W. L. 1998. "Broiler Feed Formulations with Canola Meal Based on Total or Digestible Amino Acids.” Pro. Aust. Poult. Sci. Sym. 10: 209.

[7] Wang, X., and Parsons, C. M. 1998. "Effect of Raw Material Source, Processing System and Processing Temperatures on Amino Acid Digestibility of Meat and Bone Meals.” Poultry Science 77: 834-41.

[8] Rostagno, H. S., Pupa, J. M. R., and Pac, M. 1995. "Diet Formulation for Broiler Based on Total Versus Digestible Amino Acid.” The Journal of Applied Poultry Research 4 (3): 293-9.

[9] Bryden, W. L., and Li, X. 2010. “Amino Acid Digestibility and Poultry Feed Formulation: Expression, Limitations and Application.” Revista Brasileira de Zootecnia 39: 279S-87S.

[10] Ravindran, V., and Bryden, W. L. 1999. “Amino Acid Availability in Poultry-In Vitro and in Vivo Measurements." Australian Journal of Agricultural
Research 50 (5): 889-908.

[11] AFZ, Eurolysine Ajinomoto, Nutrition Aventis Animal, INRA and ITCF. 2000. "AmiPig-Standardised Ileal Digestibility of Amino Acids in Feedstuffs for Pigs." Accessed November, 2015. http://www.feedbase.com/amipig.php?Lang=E.

[12] Bryden, W. L., and Li, X. 2004. Utilisation of Digestible Amino Acids by Broilers. Australian: Rural Industries Research and Development Corporation (RIRDC).

[13] Ravindran, V., Hew, L. I., Ravindran, G., and Bryden, W. L. 2005. "Apparent Ileal Digestibility of Amino Acids in Feed Ingredients for Broiler Chickens.” Animal Science 81 (1): 85-97.

[14] Garcia, A. R., Batal, A. B., and Dale, N. M. 2006. “A Comparison of Methods to Determine Amino Acid Digestibility of Feed Ingredients for Chickens.” Poultry Science 86 (1): 94-101.

[15] Association of Official Analytical Chemists (AOAC). 1990. Official Methods of Analysis, 15 ed.. Arlington, Virginia, USA: AOAC.

[16] Vogtmann, H., Pfirter, H. P., and Prabucki, A. L. 1975. "A New Method of Determining Metabolisability of Energy and Digestibility of Fatty Acids in Broiler Diets.” British Poultry Science 16 (5): 531-4.

[17] Thong, H. T., Chau, H. L. Q, An, N. X., and Cuong, V. C. 2014. "Determination of Basal Endogenous Protein and Amino Acids in Luong Phuong Chickens.” Journal of Animal Science and Technology 12: 14-9.

[18] NRC. 2012. Nutrition Requirements of Swine. Washington, DC: National Academy Press.

[19] Aikison, J., and Capenter, K. J. 1970. “Nutritive Value of Meat Meals II: Influence of Raw Materials and Processing on Meat Meal Quality.” Journal of the Science of Food and Agriculture 21 (7): 366-72.

[20] Skurray, G. R., and Herbert, L. S. 1974. "Batch Dry Rendering: Influence of Raw Materials and Processing Conditions." Journal of the Science of Food and Agriculture 25 (9): 1071-9.

[21] Eastoe, J. E., and Long, J. E. 1960. “The Amino Acid Composition of Processed Bones and Meat Meal.” Journal of the Science of Food and Agriculture 11 (2): 87-92. 